\title{
Short Term Paid Leave: A New Approach to Social Insurance and Employee Benefits
}

\author{
Stephen D. Sugarman $\dagger$
}

In this Article I propose an entirely new approach to incoine inaintenance for employees who are off work for temporary periods, ranging from one day up to six months, for whatever reason, including disability (from illness or injury), leisure (vacation and public hohdays) and unemployment. In lieu of the variety of existing arrangements for temporary income replacement, I advocate a new mandatory employee benefit that I call "Short Term Paid Leave."

Part I describes the Short Term Paid Leave plan and argues that it would be a substantial improvement upon existing arrangements for several reasons. Part II coinpares the Short Term Paid Leave plan with the present arrangements, usimg hypothetical einployees to demonstrate why the overwhelming majority of employees would be significantly better off under iny proposal.

\section{I}

Overview of Short Term Paid Leave

This Part first briefly describes the key features of the Short Term Paid Leave plan. I then present three broad objections to existing arrangements and explain how my plan would respond to them. Following that I address who would pay for Short Term Paid Leave. Finally, I discuss wlyy it is appropriate for government to adopt prograins that assure people reasonable levels of incoine protection during periods when they temporarily are not working.

\section{A. The Plan}

Through a simple and uniform regime, einployers would be required

$\dagger$ Professor of Law, University of California, Berkeley. B.S. 1964, J.D. 1967, Northwestern University. This proposal was in a way inspired by an article by Swedish Professor Gosta Rehn, titled Towards A Society of Free Choice, which appeared in Comparing Public Policies (Wiatr \& Rose eds. 1977). Rehn discussed his work with me in Berkeley some years ago after the publication of my book EduCation BY CHOICE (1978) (co-authored by Professor John E. Coons). That conversation showed me that the particular mixture of liberty and equality that Professor Coons and I advocated for the education system might have a counterpart in the social insurance/employee benefit system. 
by law to make certain advance arrangements for their employees' needs for income when teinporarily not working. Specifically, every einployee would earn one day of paid leave for every five days worked. Hence, soineone who works 220 days during a year (amounting to forty-four five-day weeks), would earn forty-four days (nearly nine five-day weeks) of paid leave." These paid-leave days would be accumulated in a "paid leave account" and available for employee use on a relatively unrestricted basis. A suitable present-day analogy is the typical einployee's earned vacation leave, which accrues as one works and can be drawn upon largely when and as the employee wishes.

There would be one major limit on a worker's access to his or her paid-leave account. A portion of the account would be designated the "reserve." An employee would be required to put some of each year's earned leave days into the reserve until he or she had saved six months worth of leave days. This reserve, whatever its balance, would becoine available only after an employee had been off work for two weeks owing to disability or unemployment.

A worker drawing on his or her paid-leave account would normally remain in full-pay status since, during the course of any year, earned paid-leave days would simply accrne on an employer's books. Substantial end-of-year accrued but unused balances, however, (including additions to one's "reserve") would be fully funded through employer payments into employee-controlled accounts held at designated, participating financial institutions. ${ }^{2}$

Short Term Paid Leave would replace benefits such as paid public hohidays, paid vacations, paid sick leave, teinporary disability insurance, unemployment compensation, and workers' compensation (at least for the first six months of benefits under those progranis). ${ }^{3}$ Hence, employees would have to draw upon nicome froin their paid-leave accounts whenever they temporarily were not working and wanted to be "paid." Existing long-term benefit plans, like social security and the permanent disability portion of worker's compensation, would continue to provide for needs lasting more than six months. Short Term Paid Leave, a radically simplified benefit that all employees nationwide could enjoy, would replace the current grab bag of schemes designed to satisfy einployee's short-term imcome needs.

1. People who work part time would accumulate earned paid leave in the same way: for example, one hour for every five hours worked or one half-day for every five half-days worked.

2. It might be helpful to think of these restricted accounts as analogous to individual retirement accounts (IRA) which are held in employees' names but are set aside until retirement.

3. Workers' compensation benefits providing for other than income replacement would continue-for example, medical treatment and rehabilitation costs. 


\section{B. Three Reasons Why the Plan Is Needed}

The Short Term Paid Leave plan is my solution to three different problems with the existing arrangements for temporary incoine replaceinent.

\section{Absence of a Cohesive System}

My first concern stems from the present absence of a cohesive income maintenance systein, resulting in unevenness, uncertainty, and waste. Today's short-term benefits are the product of ad hoc decisions inade over time, rather than a comprehensive approach to the teinporary mcoine replacement problem. Together, today's benefits resemble a crazy quilt that is filled with holes and jagged borders and with overlapping, and often clashing, patches. Here in brief are the inain features of the current regime.

- Workers' coinpensation, which is largely a legislatively mandated, private insurance scheme, was adopted on a state-by-state basis early im this century in response to tort law's failure to deal adequately with the inayhein of the new industrial age. Although workers' compensation covers long-term injuries as well, iny plan would only replace its provision of income-often two-thirds of prior wages up to a inodest ceiling-to those suffering from job-related, temporary disabilities.

- Unemployinent coinpensation was imposed on the states in 1935 by the federal government as a reaction to econoumic suffermg caused by the Great Depression. Although there are government-run uneinployment compensation programs in all states, as with workers' compensation, they vary significantly. In general, uneinployinent coinpensation provides up to fifty percent of prior wages, subject to a inodest ceiling, for a period of up to six months, to mvoluntarily uneinployed people who have had recent, substantial attachinent to the workforce.

- Generous vacation, public holiday, and sick leave benefits, where they are found, are largely the resnlt of post-World War II, private sector responses to employee needs and deinands. These nonmandatory benefits are a critical feature of inodern einployment for inany workers, often providing one day per inonth of fully paid sick leave, eight to twelve paid public holidays, and two to four weeks of paid annual vacation.

- Finally, in recent years, many large einployers have developed various highly complicated personnel policies designed to wrap a network of generous, private supplementary benefits around the publicly mandated ones. ${ }^{4}$ At the same time, inany workers must make do with

4. For example, some employers provide severance pay or supplemental unemployment benefits on top of required unemployment compensation, and some employers provide more generous wage replacement benefits than are required by workers' compensation. 
only the legally required programs.

One consequence of these increinental developinents, as already suggested, is that benefits vary enormously depending upon where and for whom one works. Moreover, most employees probably do not well understand their ehgibility for many of their benefits and cannot value the overall package of benefits that comes with any particular job they hold or might be considering. These imconsistencies and uncertainties should be dramatically reduced under the Short Term Paid Leave plan because benefits would be uniform and more easily calcnlated.

In order to manage the various existing programs, separate and costly bureaucracies and accounting systems, both public and private, inust be maintained. Furthermore, a great deal of attention is given to eligibility determination simce in many situations it is not clear which prograin, if any, should compensate the worker. Clannants witlı dubious eligibility now exert unwelcome pressure to qualify when the alternative is lesser benefits or none at all. Disparate public and private manageinent of today's programs also results in inconsistent enforcement and pohicing of ehgibility restrictions. Seemingly equivalent violations of eligibility requirements do not carry the same meaning or risk of discovery. By comparison, under the Short Term Paid Leave plan many bureaucracies would be eliminated, most of the currently difficult prograin eligibility decisions would no longer liave to be made, and employers would virtually never need to police employees.

While each of the current benefits seems to be amied at a separate employee need, if one steps back it becomes clear tliat at a broader level all of these benefits deal with a single problein-liow to maintain an employee's income during short-term periods when he or slie is not working (mcluding transitional periods during which an employee is moving out of the work force for a longer time or altogetler). Short Term Paid Leave offers a simple and comprehensive approacli to this broader problem, thereby promising increased coherence, uniformity, clarity, and administrative savings.

\section{Inadequacy}

My second objection to existing arrangements concerns their inadequacy. As noted above, although many employees are, in one way or another, now reasonably well protected against income loss when they are temporarily not working, many others are not. For example, a significant proportion of workers who become disabled have neitler paid sick leave (for the occasional few days of illness) nor paid temporary disability leave (for an illness or off-the-job mjury lasting for a few weeks to a 
few months). ${ }^{5}$ Holiday and vacation pay is also often provided on miserly terms, and some workers must do entirely witlout it. ${ }^{6}$ Certainly as compared both with their better-off counterparts (imcluding most public employees) and with employees througlout Western Europe, those many American workers who must depend for temporary income replacement largely upon the required social insurance benefits (unemployment and worker's compensation plans) are very poorly served indeed. ${ }^{7}$ Inadequacy, thus, is a very substantial weakness of the existing regime. A key objective of mine, therefore, lias been to develop a plan that would assure that nearly all employees have what are considered good benefits.

Similarly disadvantaged under the present arrangement are those many workers who, when they change employment, forfeit built-up rights at their old job (typically sick leave and longer amrual liolidays). Therefore, I have also souglit to assure the "portability" of benefits in my plan.

On the other side of the adequacy coin, some employees exploit (albeit legally) existing program designs. For example, certam construction workers and otlier reasonably well-paid and regularly seasonally einployed people routmely receive unemployment compensation that many consider inappropriate. ${ }^{8}$ The Short Term Paid Leave plan would also curb these sorts of excesses.

5. Soeial Security Programs in the United States, 49 Soc. SEcuRITY Bull., Jan. 1986, at 5, 37-41; Price, Cash Benefits for Short-Term Sickness: Thirty-five Years of Data, 1948-83, 49 Soc. SECURITY BULl., May 1986, at 5.

6. Full-time jobs without any paid vacation or paid hohdays are now apparently largely restricted to the retail trade, personal services, and small employers. For example, a M \& $\mathrm{M}$ Community Personnel Practices Survey dated 1984 (on file with author) identified $7.4 \%$ of employees in "retail and services to individuals" as having no paid holidays. Of the medium and large firms regularly surveyed by the Bureau of Labor Statistics, virtually all provide some paid holidays and paid vacation. See BUREAU of LABOR STATISTICS, U.S. DEP'T OF LABOR, EMPLOYEE BENEFITS IN MEDIUM AND LARGE FIRMS, 1985 (1986). About a quarter of all employees, however, enjoyed only eight days or less of paid holidays in 1985 as contrasted with the $40 \%$ who enjoyed more than 10 paid holidays. Id. at Table 6. Perhaps even inore striking, this survey found that at one year of service, $30 \%$ of employees were entitled to only one week of paid vacation. Even at five years of service, $45 \%$ of employees were entitled to only two weeks of paid vacation. Id. at Table 8 . On the history of paid vacations, see generally D. Allen, Fringe Benefits: Wages or Social Obligation? (1964).

7. For a description of the good benefits provided to its nonfaculty employees by the University of Califorma, see infra text accompanying note 21. From personal experienee and informal conversations with colleagues in Western Europe, it has bccome clear to me that in many countries at least four weeks of annual paid vacation is guaranteed to employees by law. For an international overview of social insurance benefits, see INTERNATIONAL LABOUR OFFICE, INTRODUCTION TO SOCIAL SECURIT Y (1984).

8. For further discussion of this problem, see infra text accompanying note 45 . It is worth noting here that Congress has singled out professional athletcs and school employees as seasonal workers who are undeserving of unemployment compensation benefits in their off season. For a discussion and criticism of these special provisions, see NATIONAL COMM'N ON UNEMPLOYMENT Compensation, Unemployment Compensation: Final Report 28-34 (1980). 
In sum, my plan would ensure more adequate benefits than are provided by the current schemes. Steady workers would have a benefit package that is comparable to or better than that which jobs with good benefits now provide; and erratic workers would have decent and apt protection.

\section{Lack of a Satisfactory Underlying Conception}

Third, and perhaps most importantly, my plan adopts an entirely different underlymg conception of how to deal with short-term income replacement needs. Short Term Paid Leave substitutes the forced-savings principle (through individual employee "paid leave accounts") for the existing categorical basis of eligibility for benefits. In other words, unlike some of the existing arrangements which depend upon purported or real insurance, my plan reties upon coinpelled self-insurance.

Employees face various contingencies which temporarily prevent them from working, such as illness, imjury and economic recession and instability. Traditional thinking considers these different contingencies as risks to continued wages and salaries which should be protected by separate insurance-like means. By contrast, like the typical approach to vacation pay today, under my plan paid time off is earned and accumulated as one works. The savings or self-insurance idea (together with a borrowing feature I will later discuss) ${ }^{9}$ is not only appropriately applicable to and sufficient to deal with all of the short-ternn income protection probleins that workers face, but it also avoids several undesirable features of the current arrangements.

To be eligible for benefits under the existing categorical approach it is insufficient that the employee is merely not working. The worker must satisfy one of the socially-approved, or employer-approved, categories. This approach inevitably requires the programs to make controversial decisions about who is deserving - that is, what risks are covered. For example, should an employee who leaves employment to move with his or her spouse to the spouse's new place of work receive unemployment compensation? Should one be ehigible for paid leave when home sick but not when home caring for a sick child? Under the Short Term Paid Leave plan it would now be up to the employee to decide when to use the funds put aside for his or her use, thereby substantially decreasing the feelings of unfairness that today's linedrawing creates.

Today's category-based programs also work both to restrict worker liberty and to invade worker privacy. For example, where sick-leave rules are enforced, workers must demonstrate that they are entitled to a paid sick day based on their employer's definition of the conditions that

9. See infra text accompanying note 48 . 
justify an absence. As a consequence, employees who do not feel up to work because of some physical or emotional distress that does not fall into their employer's definition of sickness, feel strongly pressured to work anyway. Similarly, under current law workers who quit their jobs often cannot get unemployment benefits even if they leave work for what to them are quite valid reasons. ${ }^{10}$ In order to qualify for benefits, they must justify being out of work by external standards that may not include their personal justifications. As a result, many employees are strongly pressured to remain in jobs that they would rather leave. Moreover, even when the employee clearly qualifies for sick leave or unemployment compensation, having to explain and defend his or her "excuse" to a third party often inposes upon the worker's dignity.

By contrast, under the Short Term Paid Leave plan, an employee's short-term income replacement benefit would be a single pool of credits that he or she has earned. Therefore, an employee would decide individually whether to draw on the fund when temporarily off work.

Since the current arrangeinents conceive of unemployment compensation as insurance that is paid for by employers, im order to prevent undeserved entitlements benefits are restricted to those people who are unemployed for reasons that do not reflect employee fault. After all, it would be an example of the classic moral hazard about which imsurers worry if workers were allowed freely to trigger the unemployment compensation benefit by their own detiberate (and possibly pleasurable) choices. Under the Short Term Paid Leave plan, by contrast, employees would, in effect, save up for their own possible unemployment. Consequently, workers could collect benefits without needing to justify their departure from work in terms of categories established by others. Moreover, there would no longer be grounds for imposing coerced work searches on the unemployed (although job-finding services would still be available to those who found them useful). Thus, Short Term Paid Leave would free workers from unwanted regulation of their hives.

Yet another inportant cost of today's categorical approach is the abuse that it generates. For example, some employees secretly work for cash while drawing unemployment compensation. ${ }^{11}$ Some claim to be home ill when they are not (especially on Monday or Friday) in order to have a paid day off without using up a vacation day. ${ }^{12}$ Sorne malinger

10. This is apart from those who quit for "good" reasons, the legal definition of which is destined to be continually in dispute.

11. For some studies of this problem, see Black \& Carr, An Analysis of Income Misreporting, and Porterfield, St. Louis, Burgess \& Kingston, Selecting Claimants for Audits of Unreported Earnings, in 2 NATIONAL COMM'N ON UNEMPLOYMENT COMPENSATION, UNEMPLOYMENT COMPENSATION: STUDIES AND RESEARCH 543, 561 (1980).

12. Although occurrence of this sort of abuse can be confirmed through conversation with any experienced benefits manager, I have found no empirical studies directed specifically at the abuse 
after an injury or illness, thereby continuing to draw benefits, when they could easily return to work. ${ }^{13}$ Soine calculatingly change their conduct in order to qualify for benefits (for example, instead of quitting, they cause theinselves to be fired so as to coine within an approved category for uneinployment compensation). ${ }^{14}$ These abuses not ouly anger supervisors and colleagues as well as the government and taxpayers, but they also deinean the cheating employees theinselves. The Short Term Paid Leave plan would largely do away with these abuses, since the incentives to cheat are radically diminished when einployees are claiming their own earned paid leave.

In suin, Short Term Paid Leave responds to all three of the objections I have raised to the current arrangements. Einployees generally would gaim freedoin, privacy, benefit portability, and a clearer understanding of what their benefits are. Many workers would have substantially improved benefits, and employers and government would benefit from reductions in both administrative costs and abuses. To be sure, soine employees would be worse off under iny proposals than at present. This would be a positive improvement in regards to abusers of the present programs and undeserving recipients. Other losers under my plan, such as workers who neghigently allow themselves to becoine ill, injured, or uneinployed on a recurrent basis, are also unlikely to win inuch sympathy.

Nevertheless, I admit that a small proportion of clearly deserving workers, those employees who now have good benefits and who are recurrently ill, injured, or uneinployed for reasons outside their control, would be worse off under iny plan. For thein, the shift from the insurance concept to the forced savings primciple would take with it the social advantages of insurance froin which they now benefit. But even these workers would not generally suffer income losses under my plan. Rather, they would, in effect, be treated as being on vacation during these periods of inactivity and would use up the paid vacation time that they had saved. I find this burden on a sinall class of workers a small price to pay for the very large gams promised by the Short Term Leave Plan.

In sum, I happily concede that the insurance primciple is needed to care for workers with long-term needs like permanent disabilities; these are rather rare and can be financially devastating. But, on the other

problem. For one interesting study of sick leave, see Winkler, The Effects of Sick Leave Policy on Teacher Absenteeism, 33 INDUS. \& LAB. REL. REV. 232 (1980).

13. For a discussion of the impact of benefits levels on malingering under current plans from the perspective of benefit managers, see Doudna, An Overview of Group Disability Income Insurance, in The HaNdBooK of EMPLOYEe BenEFITS 216-17 (J. Rosenbloom ed. 1984).

14. For a discussion of this problem and the "provoked discharge" doctrine that sometimes serves to block the employee's access to benefits, see Voluntary Leaving, 1B Unempl. Ins. Rep. (CCH) II 1975, 1975.14 (Jan. 6, 1986). 
hand, just about everyone who has a substantial attachment to the work force can reasonably take care of his or her own short-term income needs through a forced savings arrangement instead.

\section{Who Pays}

By this glowing description of its many benefits and limited shortcomings, I do not mean to suggest that the Short Term Paid Leave plan could be implemented without additional costs to anyone.

Nonetheless, for those employees who now have good benefits, the Short Term Paid Leave plan would not cost substantially more, if at all, than the benefits it would replace, especially when the reduction in abuse and costs of administration are taken imto account. Consequently, most employees with good benefits today would be even better off at essentially the same cost to their employer. It is very difficult to say whether the value of those mcreased benefits would ultimately accrue to workers, or would go to employers (because wages or other employee benefits would then go up more slowly than otherwise), or would be shared between them. For now it is enough to make the point that there is room in this reform for gams for both employees and employers.

It is more difficult to determine who would pay for the increased benefits that workers with poor benefits today would receive under the Short Term Paid Leave plan. One view is that under the plan these employees would gain a great deal for which their employers would pay. This model imagines that wages and benefits are separately determined and that newly required benefits would mean lower profits for enterprises. This view is often endorsed by employer groups and politicians who focus primarily on the formal assignment of costs. Such people often carefully distinginish between employer and employee contributions to health insurance plans, social security, and the like.

A different and probably more realistic view, however, is that employees would pay for their own improved benefits through lower wages in the long run. This inodel, usually favored by economists, argues that einployees are able to coinmand a total price for their services, which includes both cash and noncash labor costs. Other things being equal, therefore, whatever employees get in benefits they do not get in wages. I would argue that if workers under iny plan would gain benefits at the expense of current cash, on the whole they would favor this sort of trade. Moreover, if this creates serious concerns about einployee needs for cash flow, my plan would permit workers in some circumstances to convert their Short Term Paid Leave credits back into current cash. $^{15}$

15. For workers earning the minimum wage, who cannot trade lower wages for better benefits, 
It is exceedingly difficult, if not impossible, to determine the extent to which each of these two perspectives on "who pays" best describes the current situation or to predict which would prevail under my plan. In response to this ambiguity, at least to the extent practical, I have tailored my proposal so as to maintain the current balance of fiscal responsibility between employees and employers. Thus, to avoid importantly altering the burden on whomever it is that pays at present, as a formal matter, employers would fund Short Term Paid Leave benefits out of current enterprise revenues. Since the employers who would formally have to pay more under iny plan are those who currently underprovide decent benefits, many people would find this a just result whatever the ultimate incidence of such costs.

\section{Why Require Any Benefits}

At stake here is the need for income maintenance during those days, weeks, and months when people, once having gone into the labor market, temporarily do not work. ${ }^{16}$ Expenditures continue during these periods, and, unless a sharp dechine in living standards is to be experienced, soine provision must be made for contmued income. ${ }^{17}$ It is imaginable, of course, that inany, or even inost, workers could personally provide for those periods through rational planning-voluntary savings combined with private borrowing, deferral of consumption, or private insurance. Moreover, households in need because they have no member currently at work and inadequate savings have traditionally been assisted by voluntary, private income transfers that arise out of bonds of affection, felt social obligations, and altruism generally. Furthermore, there is a collectively funded safety net of "public assistance" that has emerged over the course of this century to assume a critical backup role in assuring subsistence income to those who have immediate needs for cash because of the unavailability of other sources.

While self-sufficiency, charity, and welfare might in principle take care of the problem, in practice they would not. The major fiy in the ointment is that, if left entirely to their own devices, too many people find themselves in need because they do not manage their money wisely.

my plan may be equivalent to an increase in the minimum wage. I leave the consideration of the desirability of this impact to a future, more specific discussion of the implementation of my plan.

16. I exclude from consideration here income maintenance for those young persons who have yet to become regularly attached to the labor force. Hence, $I$ will not discuss parental support rules and other existing mechanisms for funding living costs during periods of education and training of young people.

17. Many couples depend on the income of only one spouse. In sucli cases it is only when the breadwinner is not working, assuming the other spouse does not take over that role, that the family's need for regular income provision arises. In two-earner families, although a period of nonwork by one spouse is less likely to plunge the household into poverty, it still threatens to lower dramatically that household's ordinary standard of living. 
Although they might be poor enough to obtain welfare or charity in terms of need, these people are not really the targets of this aid because they could be self-sufficient, if they only planned properly. Short Term Paid Leave, thus, is perhaps best seen as a inechainsm for helping people to plan by automatically and conveniently setting aside earnings that a great consensus of workers, if properly informed, would favor.

This general point can be seen if one considers, for exainple, annual paid vacations under today's regime. Imagine an alternative systeın by which people would get higher weekly pay packets, but then would have to finance on their own a two- or three-week unpaid vacation to which they were entitled each year. Most people would probably prefer the current arrangeinents under which they are, in effect, helped (or forced) to save up for those vacations. Otherwise, many people, filled with selfregret, would find that they had spent the extra pay and could not afford to take a vacation. Even those who would take the trouble of carefully planning for a holiday period without pay probably prefer, at least in inost cases, not having to make the special effort to do so. Indeed, this notion of einployee preference-self-paternalism, it might be calledhelps to explain why we have paid vacations. ${ }^{18}$

Short Term Paid Leave simply expands upon the amount savedsubstantially beyond that needed for ordinary vacations and public hohdays. At the saine time it restricts the use of some of these savings, through the device of the "reserve," to periods of more serious need (1nore than two weeks of disability or uneinployment). That, too, is the sort of self-paternalism that inost einployees, if well informed, would probably favor.

More broadly, I wish to inake clear that I do not simply advocate overturning existing employee benefit and social insurance arrangeinents ained at workers' short-term needs for income. These collective and mutual arrangements (both public and private) play a key role in keeping people from hardship, charity, and welfare. They represent, in iny view, one of the inajor triuniphs of the inodern welfare state. In short, I do not object to either governinent intervention or einployinent-based, noncash benefit arrangeinents, but rather to their current form.

Since I am claining that employees generally would prefer their benefits in the form that I ain proposing, it inay be fairly asked why the inarket has not generated the scheine that I advocate. One reason is that the legal requireinents of uneinployment coinpensation and workers' coinpensation do not currently permit it. More broadly, the category-

18. There are other explanations for paid vacations as well; for example, employers want people to take time off in enjoyable circumstances or unions want to show workers they have obtained something besides higher wages. 
based way of thimking that lies behind those two plans has made it difficult for benefit planners even to imagine it.

Recently, however, this has begun to change a bit. Where employers and employees have room to maneuver, some employee benefit plans, such as at high technology companies like Hewlett-Packard and Bechtel, are combining sick leave and vacation pay into a smgle, earned paid time-off benefit-a kind of mim-precursor to my Short Term Paid Leave proposal. ${ }^{19}$ Indeed, Stanford Umiversity Hospital in California has had several years of successful experience with an earned time off plan that combimes the former benefits of vacations, sick leave, and public holidays. $^{20}$ Legal restrictions and lack of imagination stand in the way of further experimentation. Although I cannot do anything directly about the legal constraints, the hope of this Article is to stimulate a new way of thinking about short-term income replacement so as to make possible in the near future at least substantial experimentation with Short Term Paid Leave.

II

\section{Comparing Short Term Paid Leave with Existing ARRANGEMENTS}

For purposes of this Article, I have chosen to provide neither a systematic evaluation of the existing employee benefit arrangements nor a highly detailed description of my plan. Rather, I have elected to make some informal comparisons in hopes of generating broad interest in the proposal.

This Part first describes a package of short-term income replacement benefits of the sort that employees with what I call "good benefits" have today. I then compare that package with what Short Term Paid Leave would provide to hypothetical employees under varying circumstances. That comparison allows me both to flesh out additional irnportant details of my proposal in their appropriate contexts and to demonstrate why even employees with good benefits today would, by and large, be better off under my plan. At the same time, this analysis demonstrates the advantages of my plan to those who do not have good benefits now.

\section{A. Good Benefits Today}

Employees with good benefits generally find that their income (or at

19. See Introducing Flexible Time OfF at Hewlett-Packard (on file with author). Information about Bechtel's plan was kindly provided in a telephone interview by Susan Grisso, Manager of Corporate Policy.

20. Information about Stanford University Hospital's plan was kindly provided by Carol Ann Bergman, Manager of Human Resources (on file with author). 
least a reasonably large share of it) continues during most short-term periods when they are not at their jobs. For these employees the combination of governmentally mandated and employer provided protection fairly well sees them through the whole range of circumstances that keep them temporarily away from work-such as periods of unemployment and disability (including pregnancy), absences on account of personal and public duties (for example, family illness, funerals, and jury service), and time off intended for leisure (public holidays and vacations).

I will now describe in some detail typical good benefits, using as an example the benefit package enjoyed by staff-that is, nonfacultyemployees of the University of California. ${ }^{21}$ New full-time University of California staff employees typically earn ten hours per month or 120 hours (three weeks) per year of paid annual leave, commonly thought of as paid vacation. After ten, fifteen, and twenty years of service, respectively, paid vacation leave is increased in steps from this initial three weeks to a maximum of four weeks and four days (twenty-four days) per year. There are twelve paid holidays per year at the University of California. Employees are also ehigible for paid leave, as needed, for a few other unusual and specially identified circumstances sucl1 as jury duty.

Paid sick leave is earned at the rate of one day per montli or twelve days per year. Unused sick leave accumulates and can be used in subsequent years, but is forfeited if one leaves University employment. ${ }^{22}$ Unused vacation leave is paid out like a severance bonus when one quits or is laid off. Employees imjured at work are eligible for workers' compensation benefits, whicll are integrated with sick leave so that, in the typical case, an imjured worker uses up sick leave first, thereby initially remaining in full-pay status. After that, he or she goes over to the workers' compensation plan, which at the University of California is a combination of the state's normally required workers' compensation minimum plus a University supplement. Togetler they replace $80 \%$ of an employee's wages for up to six months.

Those who become disabled off the job and who use up their sick leave go onto the University's equivalent of California's mandated nonoccupational disability plan for the private sector; this plan provides up to six months of ouly moderate wage replacement (55\% of past wages up to a modest monthly ceiling). ${ }^{23}$ University employees may, however,

21. This information was kindly provided in a telephone interview by Betty-Lou Harmon, Manager, Compensation and Policy on the Berkeley Campus. See generally SUMMARY OF YouR BENEFITS AT THE UNIVERSITY OF CALIFORNIA (1985) (on file with author).

22. If an employee retires from the University with unused sick leave, this adds to the employee's service credit for purposes of calculating his or her retirement pension.

23. The University's traditional 26-week maximum duration for benefits is less generous than the current maximum of the state plan which is 52 weeks. Compare Cal. UNEMP. INS. CoDE $\S \S 2653,2655$ (West 1986) with Your Prudential Disability Insurance Program, University of 
purchase additional nonoccupational, temporary disability insurance that permits them to have coverage for a higher proportion of their wagesthe maximum being $70 \%$ of wages, subject to a ceiling that is rarely reached given staff salaries. Childbearing leave, typically lasting about eight weeks, is covered by these plans.

Employees who are dismissed are entitled to unemployment compensation only to the extent provided by law. For those with a reasonably substantial attachment to the work force in the year prior to losing their jobs, California's unemployment compensation scheme provides up to six months of benefits equal to $50 \%$ or less of past wages, and only up to a modest ceihing. ${ }^{24}$ Like other employees in California, those who quit their jobs at the Umiversity are generally ineligible for unemployment compensation, and there is no University supplement. However, as noted above, ${ }^{25}$ departing workers are paid for any unused vacation days, and some departing employees elect to withdraw their vested funds from the Umversity's retirement program, thereby sacrificing their pension rights, but giving themselves a financial cushion that can be used to tide them over for a while.

So long as one remains in employment at the University, the shorttern income replacement benefits are quite good by American standards. On the other hand, before one leaves employment at the University, it is wise to have another means of support already lined up, because the mcome-support benefits that are available after quitting are considerably poorer.

Based upon data released by the University, I estimate that the direct cost of the various benefits just described is approximately $15.85 \%$ of payroll as shown in Table.$^{26}$

California 1986 at 3-17 (on file with author) (describing the University's nonindustrial disability insurance program).

24. See CAL. UNEMP. INS. CoDE $\S \S 1280-1281$ (West 1986). The maximum weekly benefit is currently $\$ 166$ per week for earnings of $\$ 5533$ or more in the highest quarter of the claimant's base year (which is about $\$ 425$ per week).

25. See supra text accompanying note 22 .

26. I am confident that all the administrative costs associated with the University's short-term employee benefit system are not included in this figure. 


\section{TABLE I \\ Cost of Selected Staff Benefits at THE UNIVERSity OF CALIFORNIA ${ }^{27}$}

\section{Percentage of Payroll}

$\begin{array}{lr}\text { Annual (vacation) leave } & 6.27 \\ \text { Paid holidays } & 4.60 \\ \text { Sick leave } & 3.49 \\ \text { Workers' compensation (1) } & .34 \\ \text { Nonoccupational disability insurance (2) } & .76 \\ \text { Unemployment compensation } & .19 \\ \text { Other } & .20 \\ \text { Total } & 15.85\end{array}$

(1) Temporary income replacement portion only

(2) Assuming University were to provide maximum supplement now paid for by employees

Given the nature of the higher education industry, the pattern of einployee benefit costs is soinewhat different at the University than in other industries. For exanıple, inany other industries will have relatively higher costs for uneniploynient and/or workers' coinpensation, but will spend less on sick leave and/or paid hohidays. Overall, I have concluded that the aggregate costs of short-term inconie replaceinent benefits at the University are roughly coniparable to those incurred by other "progressive eniployers" with good benefits. ${ }^{28}$

\section{B. Comparing Short Term Paid Leave}

It should facilitate both the niaking of coinparisons and the selling of ny proposal if it can be deinonstrated that for enterprises which presently provide good benefits costs would be approximately equal under current arrangements and ny plan. With respect to the Uiniversity's program at least, that goal seems to have been satisfied. Since the rule of one day of earned leave for every five days worked nieans that one of every six days is a paid leave day, this would anount to a payroll cost of $16.7 \%$ of wages. Taking into account the reduced adıninistrative burden that the University would face under iny plan, its immediate financial costs would be inore or less the saine as current arrangements. ${ }^{29}$ These calcu-

27. This table is based upon information kindly provided by Robert $\mathbf{S}$. Kraus from the University of California, who provided his COST OF STAFF FRINGE BENEFITS (Effective August 1, 1985) (updated) (on file with author). Where readily available University data is insufficiently detailed for my needs, I have made my own estimates. As these figures are mainly illustrative, I am confident that they are sufficient for my purposes here.

28. See generally CHAMBER OF COMMERCE OF THE U.S., EMPLOYEe BENEFITS: 1983 (1984); BUREAU OF LABOR STATISTICS, U.S. DEP'T OF LABOR, supra note 6.

29. Because of the uncertainty of the actual amount of administrative costs that would be saved, it is pointless now to make more finely tuned comparisons, including, for example, adjusting 
lations, moreover, say nothing about the intangible gains that the University would achieve or the advantages most University employees would attain through Short Term Paid Leave, to which I now turn.

In making the comparisons, I consider the situations of various hypothetical employees, starting with a reasonably simple employment situation, then introducing various complications. Along the way, as appropriate, I explain additional details of my proposal as well..$^{30}$

\section{The Simple Case}

I will first discuss a new employee of the University of California who, during his or her first year of employment, takes under the Short Term Paid Leave Plan the same twelve paid holidays as he or she now gets, the same three weeks of vacation now available, and a total of four further days of paid leave when the employee is not feeling well enough to come to work or for whatever other reason. Although there would no longer be separate categories of paid leave under my plan, for comparison purposes I nonetheless identify reasons for the employee's days off. I have used four sick days so far im my illustration because evidence suggests that the great majority of workers take four or fewer sickness days per year. ${ }^{31}$ In this example, then, our hypothetical worker would have taken thirty-one paid days off and, in turn, would have worked 229-230 days during the year. Under my proposal, the one-for-five rule means that those 230 days worked would earn this employee forty-six paid-leave

for the fact that some of the $15.85 \%$ shown as Umiversity benefit costs today are "inside" payroll costs and others are "outside" or on top of payroll costs. Moreover, cost-lowering adjustments to my proposal could always be made by providing, say, one earned paid-leave day for every five and one-half days, or even six days, worked-although all of my analysis here uses the one-for-five basis.

30. One detail that I will not discuss here is the extent to which certain types of employees should be exempted from the plan on the ground that one can count on the market, as revealed by existing practices, to provide them with suitable short-term paid-leave arrangements. Indeed, given the special nature of their teaching duties as well as their pecuhar mine-month schcdule, faculty at the University of California, for example, probably should be fully outside the Short Term Paid Leave plan.

31. Unfortunately, the University of California does not have good data readily available from which a frequency distribution of sick leave taking can be constructed. Nonetheless, a California State Personnel Board's 1982-83 report, cited in Kraus, supra note 27, suggests that state employees take an annual mcan of about nine sick days, and that figure was assumed for University employees in constructing the table at note 27, supra. This estimate may well be high. In 1986, for example, the Social Security Administration estimated that state and local government employees lost an average of only seven days per year because of nonoccupational illness and aceidents. See Price, supra note 5 , at 6 .

According to Kraus in a telephone interview with the author, there is a traditional rule of thumb in this field that $20 \%$ of the employees take $80 \%$ of the sick leave. Applying this rule of thumb to the higher figure of an average of nine days of sick leave, it would appear that $80 \%$ of the workers would average only 2.25 sick leave days per year. That in turn suggests that nearly $80 \%$ of the employees probably take four or fewer sick leave days in any one year. A report from HewlettPackard presents a broadly similar finding. See INTRoDUc1NG FLEXIBLE TIME OFF AT HEWLETTPACKARD, supra note 19. 
days; thirty-one of those, as noted already, would have been used up, leaving fifteen unused.

I now consider the "reserve" feature of the Short Term Paid Leave plan. This restricted savings feature of iny proposal is designed to create a pool of funds for workers to draw against for either of two types of longer, but still temporary, needs for paid time off-that is, inore than two weeks off because of either unemployment or disability (including pregnancy). ${ }^{32}$ A full reserve contains six months, inore precisely twentyfour weeks (120 days), of paid leave. Someone with a full reserve would be able to cover six inonths out of work at full pay, subject to the twoweek waiting period.

Since the proposal inust balance the twin goals of providing substantial unrestricted leave and generating a substantial reserve, something also must be said about the rate at which employees would be required to build up their reserve. Assuine, therefore, the following rule: Fifteen days per year would have to be added when one's account has fewer than sixty days in it, ten days per year when one's account has fewer than 100 days in it, and five days per year after that and until it is complete. This rule las two important implications. First, it would take twelve years of regular work to have a full reserve, assuming that the employee does not draw against it in the ineantime. ${ }^{33}$ Second, given the build-up rate, regular workers would obtain an extra week of unrestricted earned leave after the fourth, eighth, and twelfth years of work, respectively.

In this example, therefore, the new University employee (assuming he or she came into this employment with an einpty reserve) would have to put fifteen days into his or her reserve account during the first yearwhich equals the amount of the employee's unused earned days in this hypothetical. At the end of the year, therefore, the University would pay over to a qualifying financial institution designated by the einployee a sum equal to fifteen days of pay, which would go into the einployee's "reserve" portion of his or her paid-leave account. ${ }^{34}$

32. These conditions on access to the reserve admittedly reintroduce categorical features to my plan. But these conditions are far less intrusive into the employee's privacy than are existing conditions on benefit eligibility. The two-week unemployment condition requires only that the worker has severed an employment relationship and is indifferent to the reason why the worker became unemployed. As for the disability requirement, presumably virtually everyone off work for at least two weeks owing to illness or ijjury will have seen a doctor whose certification will provide the worker access to his or her reserve funds under my plan. The point of these conditions is to make clear that access to the reserve is not to occur simply because the worker has been on holiday for two weeks.

33. Numerically this means 60 days would be built up after four years at 15 days per year. At 10 days per year for the next four years, 100 days would be built up after the eighth year. And, at five days per year for the next four years, 120 days would be built up after the 12th year.

34. When the employee draws from his or her paid-leave account (either from the reserve or froin any unrestricted portion he or she has built up), he or she could do so at a rate up to the amount of his or her then current daily wage. Although the einployer would pay into this account at 
The reason for requiring the payment of funds over to a financial institution is to minimize the risk that enployees would lose their benefits owing to the possible insolvency of their employer. On the other hand, for the administrative convenience of both employer and employee, my plan provides that at year's end employees would keep up to two weeks of unused, unrestricted earned paid leave as a credit on their employer's books. ${ }^{35}$

The hypothetical employee so far is largely in the same position under my plan as under the existing University arrangeinents-at least in the sense that $\mathrm{m}$ both cases he or she will have taken the same number of paid days off during the first year of employnent. Under the existing rules the employee would have accrued eight days of unused sick leave as well as his or her contingent rights to the various other benefits. By contrast, under my plan the enployee would now have fifteen paid days in his or her reserve. Moreover, the employee would not have to give any official reason for taking those four days off that $I$ have, for comparison purposes, termed "sick" days. And whereas the eniployee today niay be quite uncertain where he or she stands in terms of accrued benefits, it ought to be an easy matter for an employee to receive regular notice, perhaps even with each pay stub and with each quarterly statenient fron1 his or her financial imstitution, of the current status of the various elements of his or her paid-leave account. ${ }^{36}$

the employee's wage rate at the end of the year when the day was earned, the fund would be earning interest. In this way the employee ought ordmarily to be able to fund an increase he or she has won in wages between the time of earning and use of the fimds.

Mentioning yet one further detail, my plan would provide, like the treatment of vacation days today, that employees would recognize taxable income only when they actually receive the eash on a paid day off and not when they first become eligible for the funds.

35. This is only a rather small sum to have at risk in case of an employer's insolvency-like lost accrued vaeation pay in sinilar situations today. This risk is outweighed by the convenience created by the two-week accrual which allows employees to remain in full-pay status at the beginning of any calendar year when they wish to use up some unrestricted earned paid leave days from the prior year. The two-week accrual rule also helps more closely match employers' cash flow obligations under my plan with current arrangements.

Moreover, the two-week accrual rule would not give either employer or employee a financial advantage. When an employee takes a day off with pay from his or her account on the employer's books, he or she would be paid, as today, at his or her wage rate at the time he or she is off work, and not at the wage when he or she earued the day off. That is, he or she simply remains in full-pay status. An employer's current use of this money while it remains a credit on the employer's books would offset any usual increment that might occur between the time of earning and the use of the paid day off.

36. If the hypothetical employee contimues this same patteru for three more ycars, he or shc would have 60 days in his or her reserve under my plan. By contrast, under the existing University plan this worker would, after four years, have 32 days of unused sick leave built up, as well as his or her contimuing contingent rights under the other benefit programs. 


\section{Vacation Leave}

Under my plan, vacation benefits for the long-term steady worker would surpass those available under the current University arrangements starting in the fifth year of employment. In the fifth year, only ten days would have to go into the employee's reserve. As a result, the hypothetical employee could work 225 days, thereby earning forty-five days of leave, and take thirty-five paid days off-twelve as hohdays, four as "sick" days, and nineteen as vacation. This compares with fifteen days of vacation under existing policy.

The advantage of the Short Term Paid Leave plan would continue to grow in subsequent years, since additional mcrements of paid vacation would become available after the eighth and twelfth years of einployment. By contrast, the employee under the existing arrangements inust wait for his or her tenth, fifteenth, and twentieth completed years before vacation benefits are enhanced. After twelve years under my plan the hypothetical steady employee would have a full reserve of 120 paid-leave days (twenty-four weeks), and could thereafter settle into a work pattern of 216.5 work days and 43.5 paid time-off days per year-twelve public hohdays, four "sick" days, and 27.5 vacation days. This contrasts with eighteen vacation days at that point under the current rules, with the promise of twenty-one and twenty-four days to come in the future. ${ }^{37}$

If this hypothetical einployee were to remain in University employment until retirement age, never drawing on his or her reserve, then he or she could elect either to take off the last six inonths prior to retirement at full pay (and use up the paid-leave account), or to receive his or her paidleave account as a cash payment to be used as he or she wished during retireinent years. By contrast, under the existing arrangenients, an einployee who retires healthy loses those accumulated sick leave daysalthough the University now provides that they are counted as additional service credit in determining the employee's retirement pension. On balance, therefore, because of the extra vacation benefits, the long-term steady worker with an average amount of "sick" days is decidedly better off under my plan than under the existing arrangeinents.

The hypothetical einployee may not wish to use all of his or her vacation time as it becomes available but rather may want to save it up for a long break sonietime in the future. Although some einployers cur-

37. At the beginning of the 13th year, the hypothetical employee would have put aside 120 days of earned paid leave under my plan. Under existing arrangements, by contrast, he or she has 96 accumulated and unused sick days plus other contingent benefits (with even more sick days to accumulate in the future at the rate of eight per year under my assumptions so far).

As for the actual frequency distribution of vacation benefit entitlements among University of California staff, Kraus, supra note 27, reports that as of August 1, 1985, 34,245 University staff employees had under 10 years of service, 5978 had 10-15 years of service, 4176 had 15-20 years of service, and 2373 had over 20 years of service. 
rently allow this, many do not. Even the Umiversity, with its tradition of faculty sabbaticals, allows staff employees to accumulate only as much vacation as they earn in two years; after that no further annual leave is accrued, thus serving as a strong imcentive for the worker to take accumulated time off.

Longer accumulations would be permitted to everyone under the Short Term Paid Leave plan. All workers who save up a large block of days could, with reasonable notice, take lengthy breaks from work while maintaining the right to return to their jobs. ${ }^{38}$ Functionally, an employee would simply take less than all of his or her available earned paid-leave days each year. The money for those unused earned days off would, beyond the ten days' worth held by the employer for convenience reasons, be paid over to the employee's financial institution and put in his or her paid-leave account on an unrestricted basis. Note, too, that for every two weeks that an employee works rather than taking available paid leave, he or she accumulates not only the ten days of unused leave but also two additional days of leave that are earned by working those two extra weeks. This feature provides a faster accumulation of unused time off than occurs under existing arrangements.

\section{Employment Changes}

Since many workers do not have career patterns like that of the hypothetical einployee I have been discussing, I next consider a nuunber of variations on this situation. One possibility is that the worker would leave employment at the Umiversity of California, immediately take up work with an employer who today offers equivalent benefits, and then possibly change to yet a third and similar employer. Today the employee would lose semority-based paid vacation rights and sick leave status at

38. On the other hand, my plan would permit employers to require that their workers actually take at least some, although not all, of their available "vacation" each year. That is, on the ground that the enterprise benefits if its employees have some breaks in the work routine, an employer would be able to require its employees annually to take off a certain number of weeks of their earned paid leave. Moreover, as today, employers could, of course, close for public holidays and have annual shut-downs of all or parts of their operations-such as two weeks in the summer for production changes or a number of days during the Christmas to New Year period in order to save heating expenses. Employees wanting to remain in full-pay status during those periods would have to use up available earned paid leave.

Although employees would have substantial discretion as to when they use their earned paid leave, they would nonetheless have an obligation to take their employer's interests into account by giving notice when feasible, reasonably coordinating time off with the plans of fellow workers, and accommodating special employer needs at particular times of year. I do not envision an intrusive policing system to enforce this obligation. However, just as employees today are not normally thought to have complete freedom as to when to take their annual vacation, so too in the extreme cases, under my plan, employers would be free to discharge employees who abuse their paid-leave rights. Disputes over these matters would, presumably, be resolved by existing procedures set by standing company practice or provisions of union contracts. 
each job change. Accuniulated, unused sick leave with the University would disappear, as is the common practice with employers today. By contrast, under niy plan the worker's paid-leave benefits would be fully portable. ${ }^{39}$

As a result, this employee's vacation pay and reserve days for sickness or uneniployment would mcrease throughout his or her career, unaffected by job changes. This portability feature is plainly a gain for such eniployees, not only in terms of actual benefits enjoyed, but also m removing inhibitions to changing jobs. Under my plan, when the employee shifts to a new job, that position would continue to provide the saine good Short Term Paid Leave benefits. By contrast, many who leave University service today shift over to employment that provides benefits inferior to those available at the University. ${ }^{40}$

\section{Unemployment}

I have so far considered long term steady workers, whether or not they remain with one eniployer. Now let me turn to eniployees who experience gaps in their careers, thereby coinparing the protection provided by Short Term Paid Leave with that now afforded by unemploynent conipensation.

Suppose first that a worker has a six-month bout of unemployinent after twelve years of steady work, another six inonths off after a second twelve-year period of steady work, and so on. These might occur, for exaniple, because the person was undergomg retraining for a new type of work, or because he or she was searching for a new job, or because a family crisis or other personal reason caused the einployee temporarily to leave the work force. Regardless of the reason for the uneniployment, the employee under the Short Term Paid Leave Plan would have a full reserve at the time of each break im service, so he or she could take the entire six-month period of unenuployment on a fully paid basis, after the two-week waitmg period. ${ }^{41}$

By contrast, under today's regular unemploynient conipensation programs the unemployed person typically at best gets only half pay (and

39. Under iny plan he or she would receive a payout into his or her designated financial institution of any balance of unused earned leave held on the employer's books at the time of leaving employment.

40. Under iny plan people who come into a new job with a substantial reserve will, in effect, have more vacation than many others at the new place of employınent. I do not think that this will discourage employers from hiring those with built-up reserves. To the contrary, a full reserve would indicate a record of dependable work attendance.

41. An employee using his or her reserve for such bouts of unemployment would, of course, have fewer days available for vacation on return to work than he or she had before taking time out of the workforce. This parallels today's typical arrangements in which, as already noted, a new employee usually starts again at the bottom of a firn's vacation program regardless of how many years of service he or she had with a previous employer. 
usually less) for up to six inonths (subject also to a waiting period, often one week). Moreover, unless the period of unemployment is triggered by a layoff or qualifying personal reasons, typically no uneinployinent coinpensation benefits are available at all. ${ }^{42}$ Benefits are also generally denied under today's arrangements if the former employee is unavailable for work because, for example, he or she is back at school training for a new job or is taking care of some family need. When an einployinent break occurs because of the worker's choice, my plan, by contrast, inaintains the person's living standard for a reasonable time, rather than throwing the worker into potentially precarious financial straits. This additional financial security slould make employees far more able both to change career patterns and to attend to other important personal needs, thereby enhancing their hives significantly.

While these comparisons are quite favorable to Short Term Paid Leave, many people obviously are temporarily out of the work force more often than every twelve years. Yet iny plan would adequately cover these workers' needs as well. Since an einployee's reserve would be initially built up at the rate of fifteen days (three weeks) per year, he or she would be entitled to twelve weeks of fully paid breaks between jobs after every four years of work. And, since an employee could elect to draw down on his or her reserve at less than the inaximuin allowable rate, twelve weeks of fully paid leave could be stretched to twenty-four weeks of half paid leave-which is essentially equivalent to what laid off workers could, at best, expect today. In short, I am satisfied that inost people whose unemployment bouts come no more frequently than every four years would be mucli better treated during that period of uneinployment under Short Term Paid Leave as compared with current arrangements.

Even if a person is between jobs, or laid off a more-or-less regular job, for eiglit weeks every two years, he or she will still be well treated under the Short Term Paid Leave plan. After the two week waiting period, which could be covered by currently accrued earned leave days, the employee could turn to his or her reserve and there find six weeks of full pay available. This is a significant advantage for that substantial proportion of the insured unemployed who are out of work for eight weeks or less. ${ }^{43}$ For them, the theoretical advantage of twenty-six weeks of benefits under the current unemployment compensation system is not important.

42. It should be noted, however, that retraining programs occasionally carry modest stipends, and some workers permanently laid off today receive a supplemental (often lump sum) payment on severance.

43. According to a study by the Congressional Budget Office, for example, the mean duration of unemployment benefits varied between 12.3 and 15.9 weeks during the years 1970-1982. CONGRESSIONAL BUdGET OfFICE, UNEMPLOYMENT INSURANCE: FinANCIAL CoNdition AND Options for ChaNGe 22 (1983). 
Let us consider next those people whose jobs carry with them, for example, annual four-week shut downs, during which periods they currently turn to unemployment compensation to mamtain a regular flow of income. Although these funds may not be sufficient because unemployment compensation imposes a waiting period and only pays partial compensation, presumably such workers save for this time off. Short Term Paid Leave treats these annual periods for what they really are-paid vacation time that is required at the converience of the employer. Regular income would flow to workers during such mandatory time off-the first two weeks out of current paid-leave accumulations, the remainder out of their reserves.

Other employees are out of the work force for very lengthy periods, for example, a year or more. The Short Term Paid Leave plan, like existing regular unemployment compensation arrangements, is not designed to handle the needs of these people. Rather, other long-term programs are needed. ${ }^{44}$

There are still other categories of the temporarily unemployed to consider. Some workers, because of the nature of their jobs, can expect to be regularly off work for rather more than the annual four week period considered above. There are, for example, certain seasonal workers who work six months in the canning industry and then have no work for the rest of the year. Others, such as certain construction workers, know that because of the climate or the long-term work situation in their area, they are usually going to work a short year. Even though these bouts of unemployment are hardly unexpected, these seasonal employees now draw heavily on the compensation system, in many cases year after year. ${ }^{45}$ Some states have sought to restrict the access of seasonal employees to their systems. These states have had only limited success, in part because of the difficulty under the current arrangements of distingnishing by statute these claimants froin those whose long layoffs are truly unanticipated.

Workers in these sorts of mdustries, in my view, are often able to

44. Under present arrangements workers sometimes obtain modest durational additions to unemployment compensation that carry them for nine months or a year. Typically these are triggered by unusually high rates of unemployment either within a state or nationally. For a description of the extended benefit programs, see Duration of Benefits, 1B Unempl. Ins. Rep. (CCH) If 1935 (Mar. 11, 1986). Those programs could, of course, continue under the Short Term Paid Leave plan. But even they do not deal with the truly long-term unemployed, whose needs are now very poorly addressed in the United States—primarily through means-tested programs like food stamps. This problem requires reform of our long-term income maintenance programs, which, however, is not the subject of this Article.

45. For studies of and policy responses to this problem, see generally Maruizi, Unemployment Insurance and Seasonal Industries, in 2 NATIONAL COMM'N ON UNEMPLOYMENT COMPENSATION, UNEMPLOYMENT COMPENSATION: STUdies AND REsEARCh (1980) and M. MURRAY, The TREATMENT OF SEASONAL UNEMPLOYMENT UNDER UNEMPLOYMENT INSURANCE (1972). 
take inappropriate, though perfectly legal, advantage of the current system. ${ }^{46}$ After all, inany of these jobs are reasonably well paying; and inany holders of part-year jobs are not primary family breadwinners. Yet these jobs are being subsidized by the economy as a whole. That subsidy either gives the worker a windfall in the sense that his or her unemployinent is hardly the result of the "risk" the system was centrally designed to protect against; or, alternatively, and perhaps even more likely, that subsidy perimits employers to pay such workers less than their otherwise market wage because the available uneinployinent benefits are worth inore than the benefits for which the enterprise pays. Under my plan, while these short-year workers would, of course, be entitled to the Short Term Paid Leave benefits they earn while working, they would have to make other arrangements to cover longer gaps without regular paychecks. ${ }^{47}$

A yet different category of the unemployed is illustrated by the person who will wind up with a reasonably stable attachment to the work force over the long haul, but who has an unstable or unlucky start, experiencing a disproportionate share of early unemployment. On a careerlong basis this sort of worker could well self-insure his or her unemployinent experience through the reserve feature of iny plan. The problem, however, is not having cash-a sufficient reserve-at the outset. In order to deal with this sort of situation (and other similar ones), I have added a "borrowing" feature to the Short Term Paid Leave plan. The basic idea is that an employee may, under appropriate circumstances, take his or her own reserve account imto the red, by borrowing from the employee's designated financial institution. So as to assure that the funds would be forthcoming, I would have the government be a guarantor of these loans.

I propose that the maximum loan be equal to what would be that worker's full reserve-that is, twenty-four weeks of full pay. So far as repayment goes, I would require a worker whose paid-leave reserve account is in the red to bring it back into the black at a rate of twenty days of earned days per year-that is, somewhat faster than the initial, fifteen days per year, reserve build-up rate. This would, in effect, mean that the worker who had borrowed would obtain one week less vacation

46. At present, the financing of unemployment compensation is done on the basis of a payroll tax, which is partially "experience" rated; that is, employers pay a higher tax rate the more benefits their employees receive. State maxima and minima bound the operation of experience rating, however, with the result that even if seasonal employers pay into the system at the maximum rate, their employees often draw out sums in excess of the amounts that their employers paid into the system. These employers are often termed "red ink" employers.

47. Employers of such workers might well have to increase their hourly compensation or else reorganize their workforces in a more efficient way. More seasonal workers who are primary family breadwimners might find supplementary off-season work. States could choose to enact special supplemental compensation programs deliberately aimed at these classes of workers. 
a year until his or her reserve was into the black. ${ }^{48}$

Although this borrowing feature would take care of workers whose needs are timed such that they occur in advance of an adequate opportunity to save up, it is not intended to take care of the needs of all of the temporarily unemployed. Some workers who have sufficiently erratic einployınent will still be without benefits under the Short Term Paid Leave plan for periods of varying length. Many of these people, of course, are also without benefits under the current regime. For example, their unemployment is regularly considered to be their fault (for example, they are regularly fired for misconduct, refuse suitable work, or voluntarily quit their jobs). In those situations, of course, any failure of Short Term Paid Leave to provide protection is not a loss as compared with the present system.

There are some people now who recurrently lose their jobs because of bad luck (for example, their einployer or industry suffers a downturn) or imcompetence that does not amount to misconduct (or is not so argued by an employer), both of which are an employer's responsibility under the current arrangements. Soine people in this group currently obtain unemployment compensation benefits that may be better than what they could expect to get under the Short Term Paid Leave plan. Others, however, do rather poorly under the present regime because they do not have enough so-called base period employment to qualify for benefits. Of those erratic employees who are served reasonably well by the current

48. A worker's loan from his or her reserve might be ultimately secured by that worker's social security retirement account, which could be charged were the reserve still in the red when the worker wanted to retire. Perhaps this would mean delaying the worker's ability to retire on social security.

Harder issues raised by this feature are whether there would be restrictions on when a worker could borrow from his or her reserve and what imterest rate, if any, this loan would carry. It is beyond the scope of this Article to discuss these details. My instinct at present is to provide public support of the Short Term Paid Leave plan by having the government pay the interest due to the financial institution that loans the money. I also lean toward a rule that in sases of long-term, involuntarily unemployed people, the government itself would repay the loan, perhaps on the basis of a month's repayment for every six the person remains unemployed after the first six.

Although these subsidies might create demands to regulate who would be eligible to borrow, I would oppose such individual restrictions as contrary to the principles of the Short Term Paid Leave plan. On the other hand, it might be appropriate for a person under age 25 , for example, to be barred from borrowing from his or her reserve account unless he or she has logged at least, for example, two years of substantial employment during the prior three years. The general idea here is to discourage the use of the loan feature by those who are more likely to be immature borrowers if they have not had a significant recent history of regular work.

A further question would be to what extent a person could borrow if he or she had something in his or her reserve account at the start of the bout of unemployment in question. Plainly, I would allow someone with 10 weeks in his or her reserve to borrow 14 more weeks, if necessary, once those 10 had been used up. The issue rather is whether that employee with a full reserve could go 24 weeks in the red, thereby extending his or her paid unemployment period to a maximum of 48 weeks. Although there are arguments on both sides, I would allow such a worker to borrow up to the full 24 weeks. 
system, some may be abusers of the system (such as those who arrange to be fired for the purpose of collecting unemployment compensation or who secretly work for cash while drawing unemployment). The moral claim of these sorts of people to unemployment benefits is rarely stronger than that of those who have never worked but now say they would like to, and for whom the current system provides nothing.

Yet, in the end, I concede that there must be some victims of recurrent bad luck, even if relatively few in number, whose replacement mcome needs, though satisfied by today's unemployment benefits, could not be well met by the Short Term Paid Leave plan. Unless I badly underestimate the number of people in this situation, however, I conclude that the benefit of my proposal would be worth the cost of harsher treatment to these innocent victims. Moreover, so as to minimize the effects of this loss, I would favor giving such people first priority in obtaining help from the employment service. If they truly are willing workers who have had a run of bad luck, they should be relatively easy to place.

Besides, the great bulk of those employees who now have jobs with good benefits will rarely find themselves claiming unemployment compensation at all. At the Umiversity of Califormia, for example, most employees leave their jobs by quitting voluntarily. ${ }^{49}$ Finally, even if Short Term Paid Leave would provide less unemployment compensation protection for some deserving people than does today's scheme, the shift to my plan might improve their benefits in other areas. On that basis, even these hard luck workers may well be considerably better served by the Short Term Paid Leave plan than by the current system.

By this point I hope it has become reasonably clear that concerns about (1) work dismcentives created by today's unemployment compensation system, (2) whether people today are secretly working while drawing unemployment compensation benefits, and (3) whether unemployed claimants are today engaging im bona fide work searches, would largely disappear under my plan. The Short Term Paid Leave plan would provide considerable incentives for people to try to get back to work since they would be usmg up their own resources while out of work. At the same time, since claimants would have earned the money they draw from the plan, the public would feel quite differently about the claimants' right to draw upon it as they please.

\section{Disability}

Employees who are out of work for a few days each year because of sickness would, under my plan, remain in full-pay status by using up

49. Telephone interview with Betty-Lou Harmon, supra note 21 . 
earned paid-leave days. Although this would be a gain for those many workers who do not now have sick leave benefits, others, such as those who work for the University, currently remain in full-pay status so long as they have sick leave available. Under nly plan, unlike the current University plan, using up a day of earned paid leave when ill reduces available vacation days. Still, people with an average number of sick days would nonetheless have generous vacation leave under my plan, even as compared with the University's relatively hiberal vacation benefits.

Moreover, the merger of vacation and sickness leave nieans that einployees who stay healthy are rewarded with inore vacation. ${ }^{50}$ By itself, this is a desirable incentive and one which a number of employers are already embracing, albeit often in a diminished way, such as allowing workers to trade two unused sick leave days for one extra vacation day. ${ }^{51}$

To the extent that there are sick-leave abusers in an enterprise today, those einployees would have a new clear choice under iny plan. They could either take those days off as before, probably on an ad hoc one-by-one basis, or take thein on a planned basis, probably in a block, but not both. This choice may well lead to less ad hoc absenteeisn1 with workers preferring to have their available hohdays in longer periods. Also, workers might be inore inclined to give advance notice of nitended days off, rather than just calling im sick that inorning. Both of these changes would provide important scheduling and inorale benefits to einployers. To be sure, there is some chance under niy plan that some employees would choose to coine in to work when they are not feeling up to par. Given the overall generosity of the plan, however, this seems fairly unlikely.

Of course, inost people do not have a stable pattern of three or four days of illness per year. Yet, if they average three or four days per year over their work career, the Short Term Paid Leave plan allows them, in effect, to self-insure with ease. On top of that, the reserve portion of the Short Term Paid Leave account is deliberately designed for the occasional longish bout of disability that inany people suffer. Moreover, as in iny discussion of the uneniployed, someone who unluckily has a longish bout of disability near the start of his or her career (including, for exam-

50. My plan also rewards with extra later vacation those employees who are temporarily disabled but who make special efforts to recover promptly. Current programs, by contrast, try to discourage malingering by both medical oversight of the employee's condition and less than full replacement of wages.

51. Similarly, some companies provide a core package of benefits that is supplemented by earned "flexible credits" which employees discretionarily apportion among health-insurance plans, disability income, life insurance, vacations, and so forth. See, e.g., CONFERENCE BOARD, REP. No. 831, Flexible Employee Beneftr Plans: Companies' Experience (1983). As noted above, a few employers have already merged sick leave and vacation leave, treating them as a single paid time-off benefit. See supra text accompanying notes 19-20. 
ple, those novices who are injured at work when they first begin their jobs) would be able to deal with that timing problem through the borrowmg feature of my plan. In these respects, my plan broadly parallels the University's current package of protection for work and non-work disabilities (assuming that the enıployee carries the nonindustrial disability supplenient) when combined with the University's policy of permitting sick leave accumulation.

To be sure, my plan is not intended to deal with other than the temporary needs of the long-term disabled any more than it provides for the needs of the long-term unemployed. ${ }^{52}$ On the other hand, as discussed above, ${ }^{53}$ even employees with several longish bouts of temporary disabihty would fare well under my plan. And, again based on my previous discussion of the unemployed, it should be evident, for example, that with a very modest amount of plaiming and saving, women could easily arrange to have eight weeks of fully paid pregnancy leave every few years and still have good vacation leaves in between. ${ }^{54}$

My main concern about how Short Term Paid Leave would treat the disabled parallels the concern I raised about an innocent employee who is recurrently unemployed. ${ }^{55}$ Here, one should think about the person who regnlarly has to take time off work because of a chronic health problem. As before, I am not especially troubled by what would happen to those people im this group who are continually off work because of health problems caused by their own fault. ${ }^{56}$ Those who are chronically ill or recurrently mjured because of bad luck present a more troubling case, of course. Nonetheless, my concerns are at least dimmished since the general outcome for these people too would not be a loss of income. Rather, they would have to use up their paid leave while sick and not have earned paid-leave days left for genuine holidays. Moreover, the many people in this state of health who hold jobs today that carry with then 1 no temporary disability protection for causes unrelated to work would be considerably better off under iny plan. Finally, assuming chronically sick people are not likely to have accumulated sick leave, even at a place with good benefits like the Umiversity, anyone who regularly has to be out of work more than a day a month for health reasons already must dip into vacation leave in order to remain in full-pay status.

52. I nonetheless envision (as I did with the long-term unemployed) that the government would slowly repay one's loan from his or her Short Term Paid Leave account when a worker is out with an extended disability. See supra note 48.

53. See supra text accompanying note 41.

54. See supra text accompanying note 43 .

55. See supra text following note 48 .

56. Id. 


\section{Combinations}

On the bright side, by pooling a number of risks as my plan does, many people will be able, over their work careers, to self-insure their income replaceinent needs, whereas they could not do so if separate funds were earmarked for each specific contingency. For example, someone with an unusual disability experience would be better off having access to funding that would otherwise be allocated to unemployment protection that this person does not need.

On the darker side, however, those few people who unluckily combine unusual amounts of both unemployment and disability would be least able to maintain a continuous flow of income under my plan. Yet again it must not be forgotten that many of the people in these circumstances, probably a large portion of them, do not have career-long good benefit arrangements today either, thus once more minimizing the potential social costs of my plan.

\section{CONCLUSION}

The extended discussion presented in Part II of hypothetical workers and their various non-work experiences illustrates how the Short Term Paid Leave plan would function and why it ought to be a very attractive benefit scheme for nearly all employees regardless of their current benefit packages.

How should einployers react to my proposal? Assuming employees are happier with my plan as compared to current arrangements, resulting improvernents in job performance could well be the biggest gain for employers. Additional employer benefits would include administrative savings, a reduced need to police workers and to pry into their private lives, less conflict with employees over whether they qualify for certam benefits, enhanced workforce morale as employee perception of abuse by fellow workers declines, and incentives for einployees to plan and announce proposed periods off work. And while the portability of the plan's benefits would make it easier for employees to leave their jobs, it would at the sane time be easier to attract employees from other jobs.

Employers would, of course, be concerned about costs-especially those employers who do not provide good benefits now. Nonetheless, an appropriate phasing-in of my plan, combined with more research on who really pays for employee benefits, ought to reduce considerably fears and objections on this ground.

To be sure, in some einployment sectors, my plan might lead to lowered pay (or slower raises) and more time off for some workers and, at the same time, to new jobs for other workers. Retail clerks and textile workers with poor benefits at present are possible candidates here. More 
precisely, by providing existing employees with more paid time off the introduction of Short Term Paid Leave ought to force employers to expand their work force in order to maintain their current level of productive labor input. At the same time, because they would be providing better benefits, these employers ought to be able to pay lower base hourly wages. Although the plan might initially burden some employers, it could achieve a real gain in these times of continued high unemployment. ${ }^{57}$

Assuming the Short Term Paid Leave plan is a promising idea, how might it be implemented? The best strategy is probably to push for some substantial experimentation. In order to try out all of the features I propose, it would certainly help to have special exceptions from the federal government, probably Congress, with respect to existing unemployment compensation system rules. Armed with such exceptions, any state could, I believe, authorize or impose experimentation by or on some portion of its working population. ${ }^{58}$ Even without federal action, states could probably authorize employers to try out the Short Term Paid Leave plan so long as there were provisos to the effect that those who fully use up its benefits are held harmless with respect to existing unemployment compensation benefits. Even individual employers might try to experiment with my plan through contractual arrangements with workers to the effect that the workers agree not to claim either workers' compensation or unemployment compensation benefits so long as they have funds in their earned paid-leave accounts.

But it is probably too early to focus on implementation issues. What is needed first is wider discussion of the Short Term Paid Leave proposal. Were the basic idea of Short Term Paid Leave to catch on, I have little doubt that we could identify promising experiments to try.

57. There are, in addition, some broad questions my plan raises about potential macroeconomic impacts on private savings and productivity. If enough people would become sufficiently interested in my plan for those matters to be investigated seriously by economists, I would be very pleased. But so far, I do not see serious problems lurking there.

58. There is a possibly troubling question here about whether ERISA preempts statc experimentation, something I do not belicve ERISA drafters cver intended despite ambiguous language in the statute. See Kilberg \& Inman, Preemption of State Laws Relating to Employec Benefit Plans: An Analysis of ERISA Section 514, 62 TEX. L. REv. 1313 (1984); Galante, State Benefits Law Not Pre-Empted by ERISA, Nat'l Law J., Sept. 23, 1985, at 5, col. 1 (regarding the impact of ERISA on state laws regulating vacation rights). I have chosen to ignore that question here. 